\title{
PENGARUH BEBERAPA DOSIS ABU JANJANG KELAPA SAWIT TERHADAP PERTUMBUHAN BIBIT KAKAO (THEOBROMA CACAO L.)
}

(The Effect Of Some Doses Of Oil Palm Ash On The Growth Of Cacao Seedlings (Theobroma cacao L.)

\author{
Putri Diana $^{1}$, Nasrez Akhir ${ }^{2}$, Siska Efendi ${ }^{3}$ \\ ${ }^{1)}$ Alumni Program Studi Agroekoteknologi, Fakultas Pertanian, \\ Kampus III Universitas Andalas Dharmasraya. Jl. Lintas Sumatera Km 4 Pulau Punjung, Dharmasraya \\ (27612), Indonesia \\ 2) Program Studi Agroteknologi, Fakultas Pertanian, Universitas Andalas, \\ Limau Manis, Padang (25163), Indonesia \\ ${ }^{3)}$ Program Studi Agroekoteknologi, Fakultas Pertanian, \\ Kampus III Universitas Andalas Dharmasraya. Jl. Lintas Sumatera Km 4 Pulau Punjung, Dharmasraya \\ (27612), Indonesia \\ email koresponden: siskaefendi@agr.unand.ac.id
}

Article Submitted : 29-01-2020

Article Accepted : 09-02-2020

\begin{abstract}
The plant medium condition in the nursery will affect the growth of cacao seedlings. The oil Palm ash is one of the soil ameliorants because it content complete nutrient both macro and micro, the capability to increasing soil $\mathrm{pH}$ and having a high base saturation. The objectives of the research were to study the effect of oil palm ash on the growth of cacao seedlings and to get the dose for cacao in nurseries. This research was conducted in experimenta field of $3^{\text {rd }}$ Campus Andalas University Dharmasraya, in December 2018 until March 2019. The experimental method used was a Completely Randomized Design (CRD) consisted of 5 treatments and 5 replications, each of experiment unit consistend of 2 plant polybag so the total of 50 plants were obtained. The Treatments were some doses of oil palm ash of $0 \mathrm{~g}$ of oil palm ash / polybag, $150 \mathrm{~g}$ of oil palm ash / polybag, $300 \mathrm{~g}$ of oil palm ash / polybag, $450 \mathrm{~g}$ of palm oil ash / polybag, and $600 \mathrm{~g}$ of oil palm ash / polybag. Data analysis was performed by analysis of variance (F test) at the level of 5\%. If the its results are significant, then further tests with DNMRT at the level of $5 \%$. The results of the presents study showed that oil palm ash had an influence on the growth of cacao seedlings on the variabels of stem height, stem diameter, number of leaves, and the root length. The dosage of $450 \mathrm{~g}$ oil palm ash / polybag showed the best results for stem height and number of leaves of cacao seedlings, while dosage of $600 \mathrm{~g}$ oil palm ash / polybag showed the best results for stem diameter and root length of cacao seedlings. The recommended dose for cacao in the nursery is $450 \mathrm{~g}$ of oil palm ash / polybag.
\end{abstract}

Keywords : Clones, Plant Medium, Organic Fertilizer,Oil Palm Ash, and Ultisol

\section{PENDAHULUAN}

Dharmasraya merupakan salah satu kabupaten di Sumatera Barat yang memiliki komoditi kakao. Produksi kakao di Dharmasraya periode 2012- 2016 yakni
1.969 ton; 2.287 ton; 2.280 ton; 2.348 ton, dan 2033.78 ton dan diperkirakan akan terus meningkat (BPS Sumatera Barat, 2018). Berbagai upaya di lakukan pemerintah Dharmasraya untuk meningkat produksi kakao, seperti perbaikan lahan, penyediaan 
bibit unggul dan perawatan tanaman dengan menambahkan berbagai macam bibit untuk menunjang pertumbuhan kakao. Keberhasilan budidaya tanaman kakao sangat ditentukan tersedianya benih dan bibit yang baik. Bibit merupakan awal dari suatu pertanaman sehingga perlu dipersiapkan dengan baik. Kondisi tanaman selama pembibitan akan mempengaruhi pertumbuhan tanaman di lapangan sekaligus terhadap produksi tanaman tersebut. Untuk memacu pertumbuhan awal bibit kakao perlu dilakukan pemupukan, untuk menambahkan unsur hara ke dalam media pembibitan.

Umumnya jenis tanah yang terdapat di Dharmasraya adalah tanah ultisol, sehingga tanah tersebut banyak digunakan sebagai media tanam dipembibitan termasuk pembibitan kakao. Utisol merupakan jenis tanah yang tergolong tua. Tanah ini telah mengalami proses pembentukan tanah yang berjalan lanjut. Salah satu faktor yang menjadikan tanah ini tua yaitu proses pelapukan mineral dan pencucian basa-basa yang terjadi pada tanah. Proses pencucian dan pelapukan yang terjadi meninggalkan mineral-mineral yang sukar melapuk sehingga tanah menjadi masam dan miskin unsur hara (Hardjowigeno, 2003).

Kendala yang biasa ditemukan pada Ultisol adalah keasaman tanah yang tinggi, $\mathrm{pH}$ rata-rata tanah $<4,50$, kejenuhan Aluminium tinggi, miskin kandungan hara makro terutama $\mathrm{P}, \mathrm{K}, \mathrm{Ca}$, dan $\mathrm{Mg}$ dan kandungan bahan organik rendah (Prasetyo dan Suriandikarta, 2006). Pengolahan tanah ultisol untuk meminimalisir karakteristik tersebut dapat dilakukan dengan penambahan abu janjang kelapa sawit yang diharapkan dapat memperbaiki tanah tersebut. Selain budidaya kakao Dharmasraya merupakan salah satu kabupaten yang mengembangkan perkebunan kelapa sawit, bahkan Kab. Dharmasraya merupakan penghasil kelapa sawit terbesar kedua setelah Kabupaten Pasaman. Mengingat banyak pabrik kelapa sawit di Dharmasraya sehingga banyaknya limbah kelapa sawit yang dihasilkan oleh pabrik tersebut. Salah satu limbah kelapa sawit adalah tandan kosong kelapa sawit. Tandan kosong merupakan limbah organik tertinggi dibandingkan dengan limbah lain seperti kayu, pelepah, dan gulma.

Cara efisien dan cepat dalam pemanfaatan limbah tandan kosong adalah dengan membakar dan menggunakan abunya sebagai pupuk organik. Tandan yang sudah diabukan dapat dimanfaatkan untuk menetralisir keasaman dan meningkankan $\mathrm{pH}$ tanah (Kustiawan et al., 2014). Abu janjang kelapa sawit juga meningkatkan proses fotosintesis, meningkatkan ketahanan terhadap hama dan penyakit. Ditambahkan Nainggolan (1992) abu janjang mengandung Silika (SiO2) 3,33 \%; Calcium Oksida $(\mathrm{CaO}) 5,85 \%$; Magnesium Oksida $(\mathrm{MgO})$ 2,63\%; Alumunium Oksida (A12O3) 4,71\%; Feri Oksida (Fe2O3) 18,34 \%; Sulfur TriOksida (SO3) 3,0 \%; Natrium Oksida (Na2O) 1,8 \%; Kalium Oksida (K2O) 27,26 \%. Menurut Hanibal et al. (2001) abu janjang sawit mengandung unsur hara, seperti N-Total 0,05\%; P2O5 4,79 \%; $\mathrm{K} 2 \mathrm{O} 36,48 ; \mathrm{MgO} 2,63 \%$; $\mathrm{CaO} 5,46 \%$; Mn 1,230 ppm; Fe3 450 ppm; Cu 183 ppm; Zn 28 ppm dan pH 11,9 - 12,0.

Pemberian abu janjang sawit diharapkan dapat menurunkan kejenuhan alumunium yang tergolong tinggi pada Ultisol dan menyumbangkan unsur hara $\mathrm{K}$, $\mathrm{Mg}$ dan $\mathrm{Ca}$ untuk tanama. Selain itu pemberian abu janjang kelapa sawit diharapkan dapat meningkatkan $\mathrm{pH}$ dan basa-basa di dalam tanah serta dapat berpengaruh terhadap peningkatan kapasitas tukar kation efektif serta kejenuhan basa. $\mathrm{Abu}$ janjang kelapa sawit merupakan alternatif pilihan sebagai pupuk kalium karena mengandung $\mathrm{K}_{2} \mathrm{O}$ sebanyak $35-40 \%$ dan harganya jauh lebih murah dibanding KCl. Pemberian abu janjang kelapa sawit memiliki keuntungan karena mengandung kalium yang tinggi sehingga dapat mengurangi bahkan meniadakan 
penggunaan pupuk $\mathrm{KCl}$. Abu janjang kelapa sawit dilihat sebagai produk yang bernilai tinggi dan dianggap penting untuk membantu dalam meningkatkan pertumbuhan dan produksi tanaman (Pahan, 2008). Infomasi tentang pemanfaatan abu janjang kelapa sawit untuk media pembibitan kakao masih sedikit dilaporkan. Penelitian ini bertujuan untuk mempelajari pengaruh abu janjang kelapa sawit dan mendapatkan dosis abu janjang kelapa sawit yang tepat untuk pertumbuhan bibit kakao.

\section{METODE PENELITIAN}

\section{Waktu dan Tempat}

Penelitian telah dilaksanakan selama 4 bulan, terhitung dari bulan Desember 2018 sampai Maret 2019. Lokasi penelitian di lahan percobaan Kampus III Universitas Andalas Dharmasraya, Kecamatan Pulau Punjung, Kabupaten Dharmasraya, Provinsi Sumatera Barat. Abu janjang didapatkan dari PT Sumbar Andalas Kencana, Padang Laweh, Kabupaten Dharmasraya, Sumatera Barat.

\section{Rancangan Percobaan}

Penelitian ini disusun dengan Rancangan Acak Lengkap (RAL) dengan 5 perlakuan dan 5 ulangan sehingga diperoleh 25 satuan percobaan. Setiap satuan percobaan terdiri dari 2 bibit kakao sehingga diperoleh 50 tanaman sampel. Masingmasing taraf perlakuan dosis abu janjang per polybag yaitu: P0 : $0 \mathrm{~g}$ abu janjang kelapa sawit/polybag, P1 : $150 \mathrm{~g}$ abu janjang kelapa sawit/polybag, P2 : $300 \mathrm{~g}$ abu janjang kelapa sawit/polybag, P3 : $450 \mathrm{~g}$ abu janjang kelapa sawit/polybag, P4 : $600 \mathrm{~g}$ abu janjang kelapa sawit/polybag. Analisis data dilakukan dengan sidik ragam pada uji $\mathrm{F}$ pada taraf $5 \%$. Jika hasil sidik ragam berpengaruh nyata, maka dilakukan uji lanjut dengan DNMRT (5\%).

\section{Pelaksanaan Penelitian}

Areal yang digunakan dibersihkan dari gulma yang dapat menjadi sumber organisme pengganggu tanaman. Areal yang dipersiapakan diusahakan agar distribusi cahaya dan air hujan merata. Setelah pembersihan lahan dibuat naungan dan dilakukan pemasangan paranet disekeliling bibit dengan tinggi \pm 2 meter.

Persemaian kecambah disemaikan pada bak persemaian sebanyak 100 biji. Biji kakao untuk persemaian diambil dari buah bagian tengah yang masak dan sehat dari tanaman yang telah cukup umur. Biji kakao diperoleh dari tanaman induk yang telah berumur di atas 4 tahun. Biji ditanam sedalam $2 / 3$ bagian berada dalam medium dengan posisi biji mendatar dan posisi mikropil berada pada bagian bawah. Tanah yang digunakan dalam penelitian ini adalah tanah ultisol yang terdapat pada areal pembibitan yang telah dihaluskan dan dicampur dengan pupuk kandang dengan perbandingan 1:1.

Abu janjang kelapa sawit dicampurkan dengan tanah yang telah dicampur dengan pupuk kandang sesuai dengan perlakuan dan diaduk sampai homogen. Setelah itu, dimasukan ke dalam polybag ukuran $20 \times 30 \mathrm{~cm}$. Penanaman bibit dilakukan dengan memindahkan bibit dari polibag pembibitan ke dalam polybag kakao.. Kemudian bibit disusun dengan jarak antar barisan polibag $20 \mathrm{~cm}$. kemudian dilakukan pemasangan tiang standar untuk pengukuran pengamatan. Tiang standar dipasang dengan jarak $2 \mathrm{~cm}$ dari batang bibit setinggi $3 \mathrm{~cm}$.

Pemeliharaan yang dilakuakan adalah penyiraman dilakukan setiap hari sebanyak dua kali yakni pada pagi dan sore hari masing-masing sebanyak 0,5 liter setiap penyiraman. Apabila turun hujan tidak dilakukan penyiraman, penyiangan gulma dilakukan secara manual dengan pencabutan rumput yang tumbuh di media dan dilakukan 1-2 kali dalam seminggu, pengendalian hama dan penyakt dilakukan jika terdapat gejala terserangnya pada bibit tersebut. Apabila tidak ada serangan selama pembibitan maka tidak perlu dilakukan. Pemupukan sekali seminggu dengan dosis 
setengah dari rekomendasi pemupukan kakao.

\section{HASIL DAN PEMBAHASAN}

\section{Tinggi Tanaman}

Hasil analisis ragam menunjukkan bahwa perlakuan pemberian abu janjang kelapa sawit memberikan pengaruh yang nyata terhadap tinggi bibit kakao . Rata-rata tinggi bibit kakao dapat dilihat pada Tabel 1.

Tabel 1. Rata-rata tinggi bibit kakao dengan beberapa dosis abu janjang kelapa sawit pada umur 12 MST.

\begin{tabular}{cc}
\hline $\begin{array}{c}\text { Dosis Abu Janjang Kelapa } \\
\text { Sawit/polibag (g) }\end{array}$ & Tinggi Tanaman (cm) \\
\hline 0 & $34.97 \mathrm{e}$ \\
150 & $37.89 \mathrm{~d}$ \\
300 & $43.80 \mathrm{c}$ \\
450 & $50.01 \mathrm{a}$ \\
600 & $46.56 \mathrm{~b}$ \\
\hline
\end{tabular}

Pada Tabel 1 dapat dilihat bahwa tinggi tanaman tertinggi terdapat pada perlakuan dosis $450 \mathrm{~g}$ yakni $50.01 \mathrm{~cm}$ dan yang terendah pada tanaman kontrol. Hal ini disebabkan abu janjang kelapa sawit yang merupakan hasil pembakaran tandan kosong kelapa sawit yang memiliki kandungan unsur hara yang dapat membantu peroses metabolisme tanaman sehingga membantu pembentukan batang dan daun, menggemburkan tanah, menlepaskan kembali unsur hara yang terikat dalam tanah. Pemberian abu janjang kelapa sawit juga dapat meningkatkan kejenuhan basa. Peningkatan kejenuhan basa ini akan berpengaruh terhadap peningkatan ketersediaan basa-basa pada tanah. Hal itu tentu saja dapat meningkatkan serapan hara basa-basa dan metabolisme tanaman yang lebih baik sehingga berpengaruh terhadap peningkatan tinggi bibit. Menurut Utomo et al.,(2015) semakin tinggi kejenuhan basa maka semakin mudah unsur hara dilepaskan ke dalam larutan tanah atau dengan kata lain unsur hara semakin mudah tersedia bagi tanaman.

Selain itu, pemberian abu janjang kelapa sawit yang cukup pada tanah dapat memperbaiki sifat kimia tanah melalui peningkatan $\mathrm{pH}$ tanah. Kenaikan $\mathrm{pH}$ tanah meningkatkan ketersediaan hara sehingga dapat memacu pertumbuhan tinggi tanaman. Menurut Winarso (2005) $\mathrm{pH}$ tanah mempunyai pengaruh yang kuat pada ketersediaan unsur hara tanah sehingga dapat memacu pertumbuhan tanaman.

Pemberian abu janjang kelapa sawit dengan dosis $600 \mathrm{~g}$ rata-rata tinggi tanaman lebih rendah dari dosis $450 \mathrm{~g}$. Hal ini diduga terlalu banyaknya unsur hara yang disumbangkan pada tanaman sehingga dapat menjadi racun dan menghalangi pertumbuhan tanaman. Menurut Romheld (2012) menjelaskan bahwa keracunan unsur hara yang disebabkan tingginya unsur hara dalam jaringan tanaman dapat dilihat dengan tingkat pertumbuhan tanaman yang tidak meningkat banyak. Menurut Nainggolan (2011) pertumbuhan tanaman yang normal memerlukan unsur hara tertentu dan harus berada dalam jumlah dan dalam konsentrasi yang optimum serta berada dalam keseimbangan tertentu didalam tanah.

\section{Diameter Batang}

Hasil analisis ragam menunjukkan bahwa perlakuan pemberian abu janjang kelapa sawit memberikan pengaruh yang nyata terhadap diameter batang bibit kakao. 
Rata-rata diameter batang bibit kakao dapat dilihat pada Tabel 2.

Tabel 2. Rata-rata diameter batang bibit kakao dengan beberapa dosis abu janjang kelapa sawit pada umur 12 MST.

\begin{tabular}{cc}
\hline $\begin{array}{c}\text { Dosis Abu Janjang Kelapa } \\
\text { Sawit/polibag }(\mathrm{g})\end{array}$ & Diameter batang $(\mathrm{mm})$ \\
\hline 0 & $6.59 \mathrm{~b}$ \\
150 & $6.97 \mathrm{ab}$ \\
300 & $7.11 \mathrm{ab}$ \\
450 & $7.79 \mathrm{ab}$ \\
600 & $8.55 \mathrm{a}$ \\
\hline $\mathrm{KK}=9.88 \%$ & \\
\hline
\end{tabular}

Pada Tabel 2 dapat dilihat bahwa diameter tanaman yang terbesar terdapat pada pemberian dosis $600 \mathrm{~g}$ abu janjang kelapa sawit dengan rata-rata $8.55 \mathrm{~cm}$ sedangkan diameter terkecil dapat dilihat pada tanaman kontrol. Pertumbuhan diameter batang tanaman kakao pada dosis abu janjang kelapa sawit $600 \mathrm{~g}$ tidak berbeda nyata terhadap pertumbuhan tanaman dengan dosis $450 \mathrm{~g}$ dan $300 \mathrm{~g}$, dan $150 \mathrm{~g}$ namun berbeda nyata dengan pertumbuhan tanaman pada kontrol. Hal ini diduga karena abu janjang mengadung unsur $\mathrm{K}$ yang tinggi berperan dalam meningkatkan penyerapan unsur hara dan berperan dalam respirasi, transpirasi, kerja enzim dan translokasi karbohidrat yang dapat membantu dalam pertumbuhan diameter batang. Ditambahkan Suriatna (1988), ketersediaan unsur K berperan mempercepat pertumbuhan jaringan meristematik terutama batang, menguatkan tanaman dan mempengaruhi pembesaran diameter batang. Pertumbuhan diameter batang sangat dipengaruhi oleh ketersedia unsur $\mathrm{P}$ dan $\mathrm{K}$. Abu janjang kosong kelapa sawit mengandung $\mathrm{P}$ dan $\mathrm{K}$ yang tinggi yaitu $30-40 \%$ dan $7 \%$. Hal ini sesuai dengan Panjaitan et al (2003) bahwa pemberian abu janjang kosong kelapa sawit dapat meningkatkan ketersedian unsur hara seperti fosfor dan kalium. Kekurangan unsur $\mathrm{K}$ menyebabkan terhambatnya proses pembesaran batang.

\section{Jumlah Daun}

Hasil analisis ragam menunjukkan bahwa perlakuan pemberian abu janjang kelapa sawit memberikan pengaruh yang nyata terhadap jumlah daun bibit kakao. Rata-rata jumlah daun bibit kakao dapat dilihat pada Tabel 3.

Tabel 3. Rata-rata jumlah daun bibit kakao dengan beberapa dosis abu janjang kelapa sawit pada umur 12 MST.

\begin{tabular}{cc}
\hline $\begin{array}{c}\text { Dosis Abu Janjang Kelapa } \\
\text { Sawit/polibag (g) }\end{array}$ & Jumlah Daun (helai) \\
0 & $17.1 \mathrm{c}$ \\
150 & $19.6 \mathrm{~b}$ \\
300 & $19.8 \mathrm{~b}$ \\
450 & $23.7 \mathrm{a}$ \\
600 & $21.8 \mathrm{ab}$ \\
\hline $\mathrm{KK}=8.99 \%$ & \\
\hline
\end{tabular}


Tabel 3 menunjukkan bahwa jumlah daun bibit kakao terbanyak ditunjukkan pada dosis $450 \mathrm{~g}$, sedangkan jumlah daun terendah terdapat pada tanaman kontrol. Diduga karena abu janjang kelapa sawit mengandung senyawa K2O sebanyak 35,0$47,0 \%$ berperan dalam meningkatkan pertumbuhan tanaman khususnya jumlah daun. Selain K2O, abu janjang kosong kelapa sawit juga mengandung unsur $\mathrm{MgO}$ sebanyak 4-6 \% (Lampiran 6) yang berfungsi sebagai penyusun klorofil sehingga unsur ini berperan penting terhadap pertumbuhan daun. Selain itu, abu janjang juga dapat memperbaiki sifat fisik dan kimia tanah. Peningkatan serapan hara akan memacu proses fotosintesis yang menghasilkan senyawa- senyawa penting dalam proses pertumbuhan tanaman salah satunya protein. Peningkatan protein akan memacu proses pembelahan inti sel dan membentuk sel-sel baru yang menambah pertumbuhan jaringan daun tanaman.

Pertambahan jumlah daun bibit kakao tidak lepas kaitannya dengan pertambahan tinggi bibit kakao, dimana terjadi peningkatan tinggi bibit kakao maka akan meningkat juga jumlah daun bibit tersebut. Pada tanaman dengan tinggi ratarata 50.01 memiliki jumlah daun rata-rata 23.7. Hidajat (1994) menyatakan bahwa pembentukan daun berkaintan dengan tinngi tanaman. Abu janjang kelapa sawit mengandung $\mathrm{MgO}$ 4,0-6,0 \% (Lampiran 6) yang berfungsi sebagai penyusun klorofil sehingga unsur ini berperan penting terhadap pertumbuhan daun. Hal ini sesuai dengan pendapat Lakitan (2007) unsur Mg berfungsi dalam reaksi dan aktivator enzim dalam reaksi fotosintesis dan respirasi yang bergabung dengan ATP. Namun pada dosis 600 g rata-rata tinggi tanaman rendah dari dosis 450 gr abu janjang kelapa sawit. Hal ini diduga pemberian abu janjang yang berlebihan, tidak lagi mendorong pertumbuhan untuk lebih efektif, tetapi sebaliknya mulai menekan laju pertumbuhan tanaman dan menyebabkan unsur hara dalam tanah menjadi tidak seimbang dan menganggu proses fisiologis bibit kakao. Sesuai dengan yang dinyatakan Setyamijaya (1986) pemupukan yang berlebihan akan membuat larutan tanah menjadi pekat dan menghambat proses osmosis yang menghambat pertumbuhan tanaman.

\section{Panjang Akar}

Akar merupakan organ vegetatif utama yang memasok air, mineral dan bahan-bahan yang penting untuk pertumbuhan dan perkembangan tanaman. Pengukuran panjang akar dilakukan untuk mengetahui akar terpanjang dan terpendek pada bibit kakao.

Tabel 4. Panjang akar bibit kakao dengan beberapa dosis abu janjang kelapa sawit pada umur 12 MST.

\begin{tabular}{cc}
\hline $\begin{array}{c}\text { Dosis Abu Janjang Kelapa } \\
\text { Sawit/polibag (g) }\end{array}$ & Panjang akar (Cm) \\
\hline 0 & 16 \\
150 & 17 \\
300 & 20 \\
450 & 22 \\
600 & 22,2 \\
\hline
\end{tabular}

Pada Tabel 4 menunjukan bahwa panjang akar kakao berbeda, berkisaran antara 16-22,2. Hal ini diduga karena unsur $\mathrm{P}$ dan $\mathrm{K}$ untuk mendukung pertumbuhan akar tanaman yang terkandung dalam abu janjang kelapa sawit dapat diserap sempurna tanaman. Menurut Sarief (1986) unsur P berperan dalam membentuk sistem 
perakaran yang baik dan unsur $\mathrm{K}$ yang berada pada ujung akar merangsang proses pemanjangan akar. Selain menyediakan unsur hara pemberian abu janjang kosong kelapa sawit dapat memperbaiki sifat kimia tanah menjadi lebih baik. Selain itu, abu janjang kosong kelapa sawit juga mengandung unsur hara $\mathrm{Ca}$ dan $\mathrm{Mg}$. Jika meningkatnya dosis yang diberikan maka ketersediaan unsur hara menjadi meningkat sehingga akan berpengaruh terhadap perkembangan akar. Menurut Hardjowigeno (2003) pH tanah menentukan mudah tidaknya unsur-unsur hara baik makro maupun mikro diserap akar tanaman. Kecukupan unsur hara mempengaruhi pertumbuhan tanaman salah satunya panjang akar. Adanya kandungan dari abu janjang kosong kelapa sawit seperti $\mathrm{Ca}, \mathrm{Mg}$ dan $\mathrm{K}$ dapat meningkatkan basa-basa di dalam tanah sehingga kemasaman tanah dapat berkurang dan melepaskan unsur hara $\mathrm{P}$. Menurut Hardjowigeno (2003) unsur P berperan dalam transfer energi sebagai penyusun Adenosine Tri Phosphate (ATP), penyusun beberapa protein dan berperan dalam proses penyimpanan dan pemindahan energi.

\section{Rasio Tajuk Akar}

Rasio tajuk akar merupakan perbandingan antara bobot kering akar dengan bobot kering tajuk. Rasio tajuk akar bibit kakao dengan perlakuan abu janjang kelapa sawit pada pembibitan kakao dapat dilihat pada Tabel 5 .

Tabel 5. Rasio akar tajuk kakao dengan beberapa dosis abu janjang kelapa sawit pada umur 12 MST.

\section{Dosis Abu Janjang Kelapa Sawit/polibag}

(g)

$\begin{array}{cc}0 & 1,83 \\ 150 & 2,50 \\ 300 & 2,32 \\ 450 & 3,73 \\ 600 & 3,43\end{array}$

Rasio akar tajuk (gram)

pH juga mempengaruhi kenaikan kandungan kandungan $\mathrm{K}$ dan $\mathrm{P}$, semakin tinggi nilai $\mathrm{pH}$ proses dekomposisi oleh organisme juga semakin meningkat, sehingga dapat meningkatkan unsur hara tanah termasuk unsur K dan P. Menurut Sarief (1986) ketersediaan unsur hara yang diserap oleh tanaman merupakan salah satu faktor yang dapat mempengaruhi pertumbuhan tanaman sehingga ratio tajuk dan akar sama-sama dapat meningkat. Pemberian abu janjang kosong kelapa sawit dapat memperbaiki sifat fisik tanah sehingga memudahkan akar dalam menyerap unsur hara serta menigkatkan hasil fotosintesis yang akan ditranslokasikan kebagian tanaman. 
Ratio tajuk akar dalam pertumbuhan tanaman mencerminkan kemampuan tanaman dalam menyerap unsur hara serta proses metabolisme yang terjadi pada tanaman. Hasil berat kering tajuk akar menunjukan penyerapan air dan unsur hara oleh akar yang ditranslokasikan ke tajuk tanaman. Menurut Gardner et al (1991) rasio tajuk akar mempunyai pengertian bahwa pertumbuhan satu bagian tanaman diikuti dengan pertumbuhan bagian tanaman lainnya, dengan kata lain semakin baik perkembangan akar maka semakin baik pula perkembangan tajuk tanaman tersebut. Diikuti juga oleh pernyataan Sitompul dan Guritno (1995), yakni berkaitan dengan konsep keseimbangan morfologi yang berarti bahwa pertumbuhan suatu bagian tanaman diikuiti dengan pertumbuahn bagian lain, meningkatnya berat tajuk maka akan diikuiti oleh peningkatan berat akar.

\section{KESIMPULAN}

Pemberian abu janjang kelapa sawit pada tanaman kakao berpengaruh terhadap tinggi tanaman, jumlah daun, diameter batang, panjang akar, dan rasio akar tajuk bibit kakao. Dosis $450 \mathrm{~g} /$ polibag abu janjang kelapa sawit menunjukkan hasil terbaik untuk tinggi batang dan jumlah daun bibit kakao, sedangkan dosis $600 \mathrm{~g} /$ polibag abu janjang kelapa sawit menunjukkan hasil terbaik untuk diameter batang dan panjang akar.

\section{DAFTAR PUSTAKA}

Badan Pusat Statistik Sumatera Barat. 2018. Agam dalam angka laporan tahunan Bappeda: Padang.

Direktorat Jenderal Perkebunan (DITJEBUN). 2011. Luas Areal dan Produksi Perkebunan Seluruh Indonesia Menurut Pengusahaan. Jakarta: Ditjen Perkebunan.
Goenadi, Didiek Hadjar. 2005. Prospek dan Arah Pengembangan Agribisnis Kelapa Sawit di Indonesia. Badan Penelitian dan Pengembangan Pertanian, Departemen Pertanian Republik Indonesia.

Gardner, F.P.R.B Pear dan F.L. Mitaheel.1991. Fisiologi Tanaman Budidaya. Jakarta: Universita Indonesia. Terjemahan dari: Herawati Susilo dan Subianto.

Hanibal, Sarman, Gusniwati. 2001. Pemanfaatan Abu Janjang Kelapa Sawit pada Lahan Kering dan Pengaruhnya terhadap Pembentukan Nodula Akar, Pertumbuhan dan Hasil Tanaman Kedelai (Glycine max). [Skripsi]. Jambi.Fakultas Pertanian Universitas Jambi.

Hariyadi, B. W., Ali, M., \& Nurlina, N. 2017. Damage Status Assessment Of Agricultural Land As A Result Of Biomass Production In Probolinggo Regency Eats Java. Adri International Journal Of Agriculture, 1(1) : 27-47

Harjadi, S. S. 2006. Dasar-dasar Agronomi. Gramedia: Jakarta.

Hardjowigeno, S. 2003. Klasifikasi Tanah dan Pedogenesis. Akademika Pressindo: Jakarta.

Hidajat, S. 1994. Fisiologi Tumbuhan. Bandung: ITB. Terjemahan dari: Diah. R. Lukmana.

Hutagaol, H.H. 2003. Efek Interaksi Perlakuan Kapur Dolomit dan Kompos Kulit Durian terhadap $\mathrm{pH}$, P-tersedia, KTK, dan Al-dd pada Tanah Masam. [Skripsi]. Sumatera Utara. Ilmu Tanah Fakultas Pertanian. Universitas Sumatera Utara. 
Karmawati, Elna. 2010. Budidaya dan Pasca Panen Kakao.Puslitbang: Bogor.

Kelishadi, RMD. 2005. Cacao to Cacao to Chocolate: Healthy Food? Arya Journal. 1(1) : 28-34.

Kustiawan, I. 2014. Konversi Lahan Pertanian di Pantai Utara. Didalam Prisma No.1. Pustaka LP3ES: Jakarta.

Lakitan, B. 2007. Dasar-dasar Fisiologi Tumbuhan. Grafindo Persada : Jakarta.

Limbangan, J. 2012. Karakteristik Morfologis dan Anatomis Klon Harapan Tahan Penggerek Buah Kakao Sebagai Sumber Bahan Tanam. Jurnal Penelitian dan Pengembangan Pertanian 30(4): 156-163.

Lukito, A.M., Mulyono, Tetty, Y., Iswanto, H. 2004. Panduan Lengkap Budidaya Kakao. PT. Agromedia Pustaka. Pusat Penelitian Kopi dan Kakao Indonesia.

Martono, B. 2014. Karakteristik Morfologi dan Kegiatan Plama Nutfah Tanaman Kakao. Balai Penelitian Tanaman Industeri dan Penyegar Suka Bumi.

Mulyani, A., A. Rachman., dan A. Dairah. 2010. Penyebaran Lahan Masam, Potensi dan Ketersediaannya Untuk Pengembangan Pertanian. Didalam Nasional Pendayagunaan Tanah Masam. Prosiding Simposium: Bogor. Pusat Penelitian dan Pengembangan Tanah dan Agroklimat.

Mattjik, A.A., dan Sumertajaya, IM. 2006. Perancangan Percobaan dengan Aplikasi SAS dan MINITAB . Institut Pertanian Bogor Press : Bogor.
Nainggolan. 1992. Analisa Komponen Kimia dari Abu Janjang Kelapa Sawit. Laporan Penelitian. Medan: Fakultas Matematika dan Ilmu Pengetahuan Alam Universitas Sumatera Utara.

Nainggolan. B.R.A. 2011. Pemberian Pupuk NPK Organik dan Kiesrite Terhadap Pertambahan Bibit Kelapa Sawit (Elaeis guineesis Jacq) di Pembibitan Utama (Main- Nursery). [Skripsi]. Universitas Islam Riau Pekanbaru.

Pahan, I. 2008. Panduan Lengkap Kelapa Sawit. Jakarta: Penebar Swadaya.

Pamungkas, E. 2016. Berbisnis Cerdas di Budidaya kakao. Jakarta: Forrest Publishing.

Panjaitan. A., Sugiono dan H. Serait. 1983. Pengaruh Pemberian Abu Janjang Kelapa Sawit terhadap Perubahan K pada Tanah Podzolik, Regosol dan Aluvial. Medan: BPP.

Panjaitan, A., Sugijono dan H. Sirait. 2003. Pengaruh abu janjang kelapa sawit terhadap keasaman tanah Podsolik, Regosol dan Aluvial. Buletin. Balai Penelitian Perkebunan Medan.

Prasetyo, T. B. 2009. Pemanfaatan Abu Janjang Kelapa Sawit sebagai Sumber $\mathrm{K}$ pada Tanah Gambut dan Pengaruhnya Terhadap Produksi Jagung. Jurnal Solum. 2 : 95-100.

Prasetyo, B. H. Dan Suriadikarta, D. A. 2006. Karakteristik, Potensi, Dan Teknologi Pengelolaan Tanah Ultisol Untuk Pengembangan Pertanian Lahan Kering di Indonesia. Litbang Pertanian. 2(25): 39.

Pusat Penelitian Kopi dan Kakao Indonesia. 2008. Budidaya Kakao. Jakarta: Agromedia Pustaka. 
Rini. 2005. Penggunaan Dregs (Limbah Bagian Recauticizing Pabrik Pulp) dan Fly Ash (Abu Sisa Boiler Pembakaran Pabrik Pulp) untuk Meningkatkan Mutu dan Produktivitas Tanah Gambut. [Laporan Penelitian]. Pekanbaru: Lembaga Penelitian Universitas Riau.

Rizza, RA ; Liang, V., Mc. Mohan, M. dan Harrison, G. 2001. Encyclopedia of Foods: A Guide to Healthy Nutrition. London: Academic Press. 403-406.

Romheld, V. 2012. Diagnosis of deficiency and toxicity of Nutrients. In: Marschner, P. (Ed.), Marschehner's Mineral Nutrition of Higher Plants. UK: Academic Press.

Salsi, I. 2011. Karakteristik Gambut dengan Berbagai Bahan Amelioran dan Pengaruhnya Terhadap Sifat Fisik dan Kimia Guna Mendukung Produktivitas Tanah Gambut. Jurnal Agrovigor $4(1): 42-50$.

Soeverda N. Evita dan H. Arjuna. 2008. Pengaruh Beberapa Dosis Abu Janjang Kelapa Sawit Terhadap Pertumbuhan dan Hasil Kacang Hijau (Vigna radiata L.). Universitas Jambi. Jurnal Agronomi 12(2): 1-6.

Sarief, S. 1986. Kesuburan dan Pemupukan Tanah Pertanian. Bandung: Pustaka Bejana.

Setyamijaya, D. 1986. Pupuk dan Pemupukan. Jakarta: CV. Simplex.

Soeverda N, Evita dan H. Arjuna. 2008. Pengaruh Beberapa Dosis Abu Janjang Kelapa Sawit Terhadap Pertumbuhan dan Hasil Kacang Hijau (Vigna radiara L.) Universitas Jambi. Jurnal Agronomi 12(2): 1-6.
Siregar, T.H.S, S. Riyadi, L. Nuraeni. 2009. Budidaya dan Pemasaran Coklat. Jakarta: Penebar Swadaya.

\section{Budidaya Cokelat.} Jakarta: Penebar Swadaya.

Siregar, A. 2017. Pemanfaatan Abu Janjang Kelapa Sawit Sebagai Amelioran Terhadap Pertumbuhan Bibit Kelapa Sawit (Elaeis guineesis Jacq) di Pembibitan Utama (Main- Nursery). [Skripsi]. Fakultas Pertanian Universitas Andalas.

Situmorang, S. 2003. Budidaya Pengolahan Coklat. Balai Penelitian Perkebuanan Bogor. Sub Balai Penelitian Jember.

Soehardjo. 2009. Perencanaan Pangan dan Gizi. Jakarta: Bumi Aksara.

Soeratno. 2000. Pembibitan Coklat. Kumpulan Makalah Konferensi Coklat I: Medan.

Suprianto, Wawan, F. Silvina. 2016. Pengaruh Tanah Mineral dan Abu Janjang Kelapa Sawit pada Medium Gambut Terhadap Pertumbuhan Bibit Kelapa Sawit di Pembibitan Utama. JOM Fakultas Pertanian, 3(1) 1:13.

Suyoto, S \& D. Jamin. 2003. Pedoman Teknis Budidaya Coklat Bulk. PT. Perkebunan VI Pabatu: Tebing Tinggi.

Sitompul, S. M, dan Guritno, B. 1995. Analisis Pertumbuhan Tanaman. Yogyakarta: UGM Press.

Suriatna, S. 1988. Pupuk dan Pemupukan. Jakarta: Mediyatama Sarana

Syamsulbahari. 2006. Bercocok Tanam Tanaman Perkebunan Tahunan. Yogyakarta: Gadja Mada University Press. 
Syawal Y. A Kurnianingsih. Y Parto dan HIG. Hutasoit.2012. Penggunaan Abu Janjang Kelapa Sawit dan Pupuk Kandang terhadap pertumbuhan Tanaman Melon (Cucumis melo L).J. Agronomika. 1(1) : 16-25

Tjasadiharja. 2000. Beberapa Proses Fisiologi Utama Penemu Coklat. Kumpulan Jurnal Komperensi Nasional Coklat I (1). 66-75

Tjitrosoepomo, Gembong. 1988. Taksonomi Tumbuhan (Sperma thopyta), Yogyakarta : Universitas Gadjah Mada.
Utomo, B. 2008. Pengaruh Dolomit dan Pupuk P Terhadap Pertumbuhan dan Hasil Tanaman Kacang Tanah (Arachis hypogea) di Tanah Incepsol. Medan: Fakultas Pertanian Universitas Sumantera Utara .

Utomo, S., Sudarsono, B. Rusman, T. Sabrina, J. Lumbanaraja dan Wawan. 2015. Ilmu Tanah Dasar-dasar dan Pengolahan. Lampung: Kencana Prenada Media Gruop.

Winarso, S. 2005. Kesuburan Tanah Dasar Kesehatan dan Kualita Tanah. Yogyakarta: Gava Media. 